\title{
Analisis Nilai Investasi Bangunan Dan Pemanfaatan Ruang Wilayah Untuk Kebutuhan Penilaian Daya Dukung Daerah Aliran Sungai (DDD) Rokan Insan Ikhsan ${ }^{1}$, Manyuk Fauzi $^{2}$ Sigit Sutikno $^{3}$ \\ ${ }^{1}$ Mahasiswa Program Magister Teknik Sipil Bidang Konsentrasi Hidroteknik Fakultas Teknik Universitas Riau, Pekanbaru 28293 E-mail : insan0998@gmail.com \\ 2,3 Jurusan Teknik Sipil Fakultas Teknik Universitas Riau, Pekanbaru 28293
}

\begin{abstract}
Abstrak-Tujuan utama penelitian adalah melakukan analisis nilai investasi bangunan sebagai monitoring dan evaluasi investasi bangunan untuk mengetahui besar kecilnya sumber daya buatan manusia yang telah dibangun di DAS yang perlu dilindungi dari kerusakan yang disebabkan oleh degradasi DAS dan pemanfaatan ruang wilayah adalah untuk mengetahui perubahan kondisi kawasan lindung dan kawasan budidaya terkait ada tidak adanya kecenderungan pemanfaatan lahan yang menyebabkan kawasan dimaksud terdegradasi dari waktu ke waktu. Metode pendekatan yang digunakan adalah menggunakan pendekatan Peraturan Menteri Kehutanan No. 61/ Menhut - II/ 2014 Republik Indonesia tentang Monitoring dan Evaluasi Pengelolaan DAS. Adapun data yang dipergunakan untuk kebutuhan analisis adalah jumlah penduduk, nilai investasi bangunan air, luas liputan vegetasi, luas kawasan lindung dalam DAS, luas lahan dengan lereng $0-25^{\circ}$ dan luas kawasan budidaya dalam DAS yang bersumber dari Badan Pusat Statistik (BPS) Provinsi Riau, BP-DASHL Indragiri Rokan dan Dinas PUPR Provinsi Riau. Hasil utama penelitian membuktikan bahwa nilai investasi bangunan dan pemanfaatan ruang wilayah memberikan sumbangan nilai 17.5 untuk kebutuhan analisis kebutuhan daya dukung DAS Rokan
\end{abstract}

Kata kunci: DAS, daya dukung, nilai investasi bangunan, pemanfatan ruang wilayah.

Abstract-The main objective of the study is to analyze the value of building investment as a monitoring and evaluation of building investment to determine the size of man-made resources that have been built in watersheds that need to be protected from damage caused by watershed degradation and use of regional space to determine changes in protected area conditions and related cultivation areas there is no tendency for land use to cause the area to be degraded from time to time. The approach method used is using the approach of Forestry Minister Regulation No. 61 / Menhut - II / 2014 Republic of Indonesia concerning Monitoring and Evaluation of Watershed Management. The data used for analysis needs are population, investment value of water building, area of vegetation coverage, area of protected area in the watershed, land area with slopes $0-25^{\circ}$ and area of cultivation in the watershed sourced from the Central Bureau of Statistics (BPS) Riau Province, BP-DASHL Indragiri Rokan and PUPR Office in Riau Province. The main results of the study prove that the value of building investment and utilization of regional space contributes values 17.5 for the needs of the analysis of the carrying capacity of the Rokan Watershed

Keywords :carrying capacity, utilization of regional space, value of building investment, watershed

\section{I.PENDAHULUAN}

Daerah Aliran Sungai (DAS) merupakan satu kesatuan ekosistem alami yang utuh dari hulu hingga hilir. DAS bukan hanya sungai tetapi mencakup wilayah daratan di atas badan sungai yang batasnya di daratan berupa pemisah topografis dan batas di laut sampai dengan daerah perairan yang masih terpengaruh aktivitas daratan (Asdak, 2010). 
Selanjutnya masih bersumber dari Permenhut No 61/Menhut II/2014) bahwa DAS dapat dipandang sebagai sistem alami yang menjadi tempat berlangsungnya proses-proses biofisik hidrologis maupun kegiatan sosial-ekonomi masyarakat yang kompleks. Proses-proses biofisik hidrologis DAS merupakan proses alami sebagai bagian dari suatu daur hidrologi atau yang dikenal sebagai siklus air. Sedang kegiatan sosial- ekonomi masyarakat merupakan bentuk intervensi manusia terhadap sistem alami DAS, seperti pengembangan perkotaan, pembuatan bangunan air, pengembangan lahan kawasan lindung dan budidaya. Hal ini tidak lepas dari semakin meningkatnya tuntutan atas sumber daya alam (air, tanah, dan hutan) yang menyebabkan meningkatnya tekanan penduduk terhadap lahan yang membawa akibat pada perubahan kondisi daya dukung DAS.

Masih bersumber dari Permenhut No 61/Menhut II/2014 bahwa perubahan kondisi daya dukung DAS sebagai dampak pemanfaatan lahan yang tidak terkendali tanpa memperhatikan kaidah-kaidah konservasi tanah dan air dapat mengakibatkan peningkatan erosi dan sedimentasi, penurunan penutupan vegetasi, dan percepatan degradasi lahan. Hasil akhir perubahan ini tidak hanya berdampak nyata secara biofisik berupa peningkatan luas lahan kritis, penurunan kuantitas, kualitas dan kontinyuitas aliran, namun juga secara sosial ekonomi menyebabkan masyarakat menjadi semakin kehilangan kemampuan untuk berusaha di lahannya dan penurunan kesejahteraan masyarakat.

Penerapan penilaian daya dukung DAS menggunakan pendekatan P.61/Menhut II/ 2014 telah diterapkan melalui kajian Penyusunan Rencana Umum Pengelolaan DAS Kampar pada tahun 2015 oleh Pusat Pengendalian Pembangunan Ekoregian Sumatera (P3ES). Hasil utama kajian menyatakan bahwa kondisi DAS Kampar memiliki nilai 112.5 dengan klasifikasi daya dukung DAS dalam keadaan kondisi buruk dengan rentang nilai $110<$ DDDAS $<130$. Hasil penilaian daya dukung DAS Kampar dengan klasifikasi buruk selanjutnya dapat dipergunakan sebagai bahan pertimbangan untuk Penyusunan Rencana Aksi terhadap upaya Pengelolaan pada DAS Kampar yang berkelanjutan.
Merujuk dari latar belakang penelitian tersebut di atas, maka tujuan utama dari penelitian ini adalah melakukan analisis khususnya terhadap kriteria nilai investasi bangunan dan kriteria pemanfaatan ruang wilayah yang memberikan sumbangan penilaian sebesar 20 poin atau setara $20 \%$ terhadap penilaian Daya Dukung DAS total untuk komponen keseluruhan lima kriteria monitoring dan evaluasi yang meliputi lahan, kualitas dan kuantitas kontinuitas air, sosial ekonomi, investasi bangunan dan pemanfaatan ruang wilayah sehingga hasil penelitian ini dapat untuk mengetahui besar kecilnya sumber daya buatan manusia yang telah dibangun di DAS Rokan yang perlu dilindungi dari kerusakan yang disebabkan oleh degradasi DAS Rokan dan pemanfaatan ruang wilayah adalah untuk mengetahui perubahan kondisi kawasan lindung dan kawasan budidaya terkait ada tidak adanya kecenderungan pemanfaatan lahan yang menyebabkan kawasan dimaksud terdegradasi dari waktu ke waktu.

\section{LANDASAN PUSTAKA}

\section{Komponen Monitoring dan Evaluasi Daya Dukung DAS}

Masih bersumber dari Permenhut No 61/Menhut II/2014 Kementerian Kehutanan Republik Indonesia bahwa ruang lingkup kegiatan monitoring dan evaluasi pengelolaan DAS mencakup :

1. Monitoring dan evaluasi lahan: lahan kritis, penutupan vegetasi dan indeks erosi.

2. Monitoring dan evaluasi kualitas, kuantitas dan kontinuitas air: koefisien regim aliran, koefisien aliran tahunan, muatan sedimen, banjir dan indeks penggunaan air.

3. Monitoring dan evaluasi sosial ekonomi: tekanan penduduk, tingkat kesejahteraan, keberadaan dan penegakan hukum.

4. Monitoring dan evaluasi investasi bangunan: keberadaan dan status kota dan nilai investasi bangunan air.

5. Monitoring dan evaluasi pemanfaatan ruang wilayah: kondisi kawasan lindung dan kondisi kawasan budidaya.

\section{Monitoring dan Evaluasi Investasi Bangunan}

Monitoring dan Evaluasi kriteria Investasi Bangunan bertujuan untuk mengetahui besar kecilnya sumber daya buatan manusia yang telah dibangun di DAS yang perlu dilindungi dari kerusakan yang disebabkan oleh 
degradasi DAS. Semakin besar nilai investasi bangunan dimaksud semakin besar keperluan untuk melindunginya. Bangunan di DAS yang dimonitor dan dievaluasi meliputi keberadaan dan status/kategori kota dan nilai terkini bangunan air. Berdasarkan peran/pengaruh investasi bangunan di DAS maka pembobotan untuk kriteria nilai investasi bangunan air dalam monitoring dan evaluasi pengelolaan DAS ini adalah 10, sedangkan untuk masing-masing sub kriteria adalah sebagai berikut : klasifikasi kota (5) dan klasifikasi bangunan air (5).

\section{Monitoring dan Evaluasi Sub Kriteria Klasifikasi Kota}

Monitoring dan evaluasi klasifikasi kota dilakukan untuk mengetahui keberadaan dan status/kategori kota di DAS. Menurut Peraturan Pemerintah Nomor 26 Tahun 2008 tentang Rencana Tata Ruang Wilayah Nasional (RTRWN), kawasan perkotaan adalah wilayah yang mempunyai kegiatan utama bukan pertanian dengan susunan fungsi kawasan sebagai tempat permukiman perkotaan, pemusatan dan distribusi pelayanan jasa pemerintahan, pelayanan sosial, dan kegiatan ekonomi. Berdasarkan jumlah penduduknya, kriteria kawasan perkotaan diklasifikasikan sebagaimana Tabel 1 di bawah ini

Tabel 1. Kriteria Kawasan Perkotaan Berdasarkan Jumlah Penduduk

\begin{tabular}{|l|l|l|}
\hline No & $\begin{array}{l}\text { Kawasan } \\
\text { Perkotaan }\end{array}$ & $\begin{array}{l}\text { Jumlah Penduduk } \\
\text { (jiwa) }\end{array}$ \\
\hline 1 & $\begin{array}{l}\text { Perkotaan } \\
\text { Kecil }\end{array}$ & $>50-100$ \\
\hline 2 & $\begin{array}{l}\text { Perkotaan } \\
\text { Sedang }\end{array}$ & $100.000-500.000$ \\
\hline 3 & $\begin{array}{l}\text { Perkotaan } \\
\text { Besar }\end{array}$ & $>500.000$ \\
\hline 4 & Metropolitan & $>1.000 .000$ \\
\hline
\end{tabular}

Sumber : P.61 / Menhut II/2014

Adapun informasi data klasifikasi kota berdasarkan jumlah penduduk diperoleh dari Kementerian Pekerjaan Umum dan Perumahan Rakyat, Kementerian Dalam Negeri dan Badan Pusat Statistik (BPS). Apabila di DAS terdapat lebih dari satu status/kategori kota maka digunakan status/kategori kota yang mempunyai kelas tertinggi. Perhitungan keberadaan dan status kota menggunakan klasifikasi nilai disajikan pada Tabel 2 di bawah ini.
Tabel 2. Sub Kriteria, Bobot, Nilai dan Klasifikasi Kota

\begin{tabular}{|c|c|c|c|c|}
\hline $\begin{array}{c}\text { Sub } \\
\text { Kriteria }\end{array}$ & $\begin{array}{c}\text { Bobo } \\
t\end{array}$ & $\begin{array}{c}\text { Nilai } \\
\text { (milyar) }\end{array}$ & Kelas & Skor \\
\hline $\begin{array}{l}\text { Nilai } \\
\text { Bangunan } \\
\text { Air }\end{array}$ & 5 & $\begin{array}{l}\text { Tidak ada } \\
\text { Kota } \\
\text { Kota Kecil } \\
\text { Kota } \\
\text { Sedang } \\
\text { Kota Besar } \\
\text { Metropolita } \\
\text { n }\end{array}$ & $\begin{array}{l}\text { Sangat } \\
\text { Renda } \\
\mathrm{h} \\
\text { Renda } \\
\mathrm{h} \\
\text { Sedan } \\
\mathrm{g} \\
\text { Tinggi } \\
\text { Sangat } \\
\text { Tinggi }\end{array}$ & $\begin{array}{l}0.50 \\
\\
0.75 \\
1.00 \\
1.25 \\
1.50\end{array}$ \\
\hline
\end{tabular}

Sumber : P.61 / Menhut II/2014

\section{Monitoring dan Evaluasi Sub Kriteria Klasifikasi Nilai Bangunan Air}

Monitoring dan evaluasi nilai bangunan air dilakukan untuk mengetahui nilai bangunan air (dalam rupiah) di DAS. Bangunan air yang dimaksud adalah waduk, dam, bendungan dan saluran irigasi. Data nilai bangunan air diperoleh dari Kementerian Pekerjaan Umum dan Perumahan Rakyat dan Dinas/instansi yang membidangi pengairan di provinsi/ kabupaten /kota. Perhitungan nilai bangunan air menggunakan klasifikasi nilai disajikan seperti pada Tabel 3 di bawah ini.

Tabel 3 Sub Kriteria, Bobot, Nilai dan Klasifikasi Nilai Bangunan Air

\begin{tabular}{|l|l|l|l|l|}
\hline $\begin{array}{c}\text { Sub } \\
\text { Kriteria }\end{array}$ & $\begin{array}{c}\text { Bobo } \\
\mathrm{t}\end{array}$ & $\begin{array}{c}\text { Nilai } \\
\text { (milyar) }\end{array}$ & Kelas & Skor \\
\hline $\begin{array}{l}\text { Klasifikas } \\
\text { i Kota }\end{array}$ & 5 & IBA $<15$ & $\begin{array}{l}\text { Sangat } \\
\text { Renda }\end{array}$ & 0.50 \\
& & $15<$ IBA $<3$ & h & 0.75 \\
& & 0 & Renda & 1.00 \\
& & $50<$ IBA $<4$ & h & 1.25 \\
& & $45<$ IBA $<6$ & Sedan & 1.50 \\
& & g & \\
& & IBA $>60$ & Tinggi & \\
& & & Sangat & \\
& & & & \\
& & &
\end{tabular}

Sumber : P.61 / Menhut II/2014 


\section{Monitoring dan Evaluasi Pemanfaatan Ruang Wilayah}

Monitoring dan evaluasi pemanfaatan ruang wilayah dimaksudkan untuk mengetahui tingkat daya dukung lahan sebagai akibat dari kondisi pemanfaatan ruang wilayah DAS. Data yang dikumpulkan dalam monitoring dan evaluasi pemanfaatan ruang wilayah adalah data dari hasil observasi di lapangan yang ditunjang dengan data dari sistem penginderaan jauh dan data sekunder.

Tujuan dari monitoring dan evaluasi pemanfaatan ruang wilayah adalah untuk mengetahui perubahan kondisi kawasan lindung dan kawasan budidaya terkait ada tidak adanya kecenderungan pemanfaatan lahan yang menyebabkan kawasan dimaksud terdegradasi dari waktu ke waktu. Semakin sesuai kondisi lingkungan dengan fungsi kawasan maka kondisi DAS semakin baik dan sebaliknya apabila tidak sesuai fungsinya maka kondisi DAS semakin jelek.

Berdasarkan peran/pengaruh pemanfaatan ruang wilayah terhadap kondisi daya dukung DAS maka pembobotan untuk kriteria ini dalam monitoring dan evaluasi pengelolaan DAS adalah 10, sedangkan untuk masing-masing sub kriteria adalah sebagai berikut : kawasan Lindung adalah 5 dan kawasan Budidaya adalah 5.

\section{Monitoring dan Evaluasi Sub Kriteria Kawasan Lindung}

Monitoring dan evaluasi kondisi kawasan lindung dilakukan untuk mengetahui persentasi liputan vegetasi di dalam kawasan lindung, yang merupakan perbandingan luas liputan vegetasi di dalam kawasan lindung dengan luas kawasan lindung dalam DAS. Dengan demikian sub kriteria ini sebenarnya juga untuk melihat kesesuaian peruntukan lahan mengingat Kawasan Lindung sebagian besar terdiri atas Kawasan Hutan.

Wilayah yang termasuk kawasan lindung adalah hutan Lindung dan hutan Konservasi (cagar alam, suaka margasatwa, taman buru, taman hutan rakyat, taman wisata alam dan taman nasional) dan kawasan lindung lainnya. Data diperoleh dari BKSDA, BTN, BPN dan BPKH. Untuk data liputan hutan diperoleh dari data sekunder hasil identifikasi citra satelit/citra resolusi tinggi/liputan lahan yang dilaksanakan oleh Kementerian Lingkungan Hidup Kehutanan (LHK) /Badan Informasi Geospasial
(BIG) /LAPAN/pihak lain sesuai kewenangannya. Untuk parameter Kawasan Lindung (KL) selanjutnya dapat dihitung menggunakan persamaan 1 sebagai berikut

$$
K L=\frac{L L V}{L K L} x 100 \% \ldots \ldots \ldots \ldots . . .(1)
$$

Dimana KL adalah kawasan lindung dalam ha, LLV adalah luas liputan vegetasi dalam ha dan LKL adalah luas kawasan lindung dalam DAS dalam ha

Adapun perhitungan kawasan lindung menggunakan klasifikasi nilai disajikan seperti pada Tabel 3 di bawah ini.

Tabel 3. Sub Kriteria, Bobot, Nilai dan Klasifikasi Kawasan Lindung

\begin{tabular}{|c|c|c|c|c|}
\hline $\begin{array}{c}\text { Sub } \\
\text { Kriteria } \\
\end{array}$ & $\begin{array}{c}\text { Bobo } \\
\mathrm{t}\end{array}$ & $\begin{array}{c}\text { Nilai } \\
\text { (milyar) }\end{array}$ & Kelas & Skor \\
\hline $\begin{array}{l}\text { Kawasan } \\
\text { lindung } \\
(\mathrm{KL})\end{array}$ & 5 & $\begin{array}{l}\mathrm{KL}>70 \\
45<\mathrm{KL}<70 \\
30<\mathrm{KL}<45 \\
15<\mathrm{KL}<30 \\
\mathrm{KL}<15\end{array}$ & $\begin{array}{l}\text { Sangat } \\
\text { Baik } \\
\text { Baik } \\
\text { Sedan } \\
\mathrm{g} \\
\text { Buruk } \\
\text { Sangat } \\
\text { Buruk }\end{array}$ & $\begin{array}{l}0.50 \\
\\
0.75 \\
1.00 \\
1.25 \\
1.50\end{array}$ \\
\hline
\end{tabular}

Sumber : P.61 / Menhut II/2014

\section{Monitoring dan Evaluasi Sub Kriteria Kawasan Budidaya}

Monitoring dan evaluasi kondisi kawasan budidaya dilakukan untuk mengetahui persentase luas lahan dengan kelerengan 0-25\% pada kawasan budidaya, yang merupakan perbandingan luas total lahan dengan kelerengan $0-25 \%$ yang berada pada kawasan budidaya dengan luas kawasan budidaya dalam DAS.

Kelas kelerengan 0-25\% merupakan kelas lereng yang paling sesuai untuk budidaya tanaman sehingga akan cocok berada pada kawasan budidaya. Semakin tinggi persentase luas unit lahan dengan kelerengan 0-25\% pada kawasan budidaya maka kondisi DAS semakin baik. Sebaliknya semakin rendah persentase luas unit lahan dengan kelerengan $0-25 \%$ pada kawasan budidaya, atau dengan kata lain semakin tinggi persentase luas unit lahan dengan kelerengan $>25 \%$ pada kawasan budidaya maka kondisi DAS semakin 
tinggi.

Untuk parameter Kawasan Budidaya (KB) dapat dihitung menggunakan persamaan 2 sebagai berikut

$$
K B=\frac{L L D L(0-25 \%)}{L K B} \times 100 \%
$$

Dimana KB adalah kawasan budidaya dalam ha, LLDL 0 - 25\% adalah luas lahan dengan lereng 0 - 25 $\%$ dalam ha dan LKB adalah luas kawasan budidaya dalam DAS dalam ha

Adapun perhitungan kawasan Budidaya menggunakan klasifikasi nilai disajikan seperti pada Tabel 4 di bawah ini.

Tabel 4. Sub Kriteria, Bobot, Nilai dan Klasifikasi Kawasan Budidaya

\begin{tabular}{|c|c|c|c|c|}
\hline $\begin{array}{c}\text { Sub } \\
\text { Kriteria }\end{array}$ & $\begin{array}{c}\text { Bobo } \\
t\end{array}$ & $\begin{array}{c}\text { Nilai } \\
\text { (milyar) }\end{array}$ & Kelas & Skor \\
\hline $\begin{array}{l}\text { Kawasan } \\
\text { Budidaya } \\
(\mathrm{KB})\end{array}$ & 5 & $\begin{array}{l}\mathrm{KB}>70 \\
45<\mathrm{KB}<70 \\
30<\mathrm{KB}<45 \\
15<\mathrm{KB}<30 \\
\mathrm{~KB}<15\end{array}$ & $\begin{array}{l}\text { Sangat } \\
\text { Renda } \\
\mathrm{h} \\
\text { Renda } \\
\mathrm{h} \\
\text { Sedan } \\
\mathrm{g} \\
\text { Tinggi } \\
\text { Sangat } \\
\text { Tinggi }\end{array}$ & $\begin{array}{l}0.50 \\
\\
0.75 \\
1.00 \\
1.25 \\
1.50\end{array}$ \\
\hline
\end{tabular}

Sumber : P.61 / Menhut II/2014

\section{METODE PENELITIAN}

Metode penelitian disusun berdasarkan latar belakang penelitian, identifikasi masalah, perumusan masalah serta tujuan utama dari penelitian.

\section{Lokasi Penelitian}

DAS Rokan merupakan salah satu DAS yang terletak di Pulau Sumatera yang berhulu di Pegunungan Bukit Barisan dan berhilir di pantai timur Sumatera. Secara astronomis, DAS Rokan terletak antara $0^{\circ} 3^{\prime} 58.03 " \mathrm{~N}$ LU sampai $2^{\circ} 18^{\prime} 6.39^{\prime \prime} \mathrm{LU}$ dan $99^{\circ} 41^{\prime} 35.19^{\prime \prime} \mathrm{BT}$ sampai $101^{\circ} 18^{\prime}$ 56.21" BT. Adapun secara administrasi DAS Rokan terletak di tiga wilayah provinsi, yaitu Provinsi Riau, Provinsi Sumatera Barat dan Provinsi Sumatera Utara, yang terdiri atas terdiri atas 12 Kabupaten dan 52 Kecamatan. Peta
Administrasi DAS Rokan selanjutnya disajikan seperti pada Gambar di bawah ini

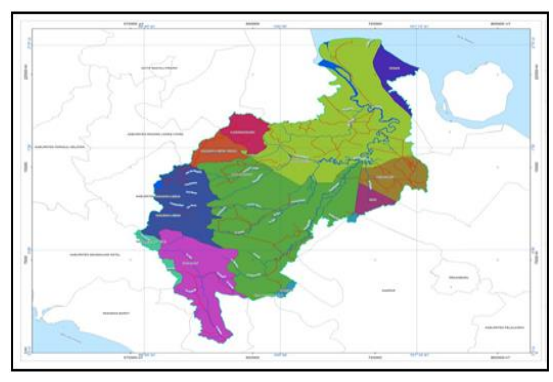

Gambar 1. Peta Administrasi DAS Rokan

\section{Kebutuhan Data}

Data yang diperlukan dalam penyusunan analisis daya dukung DAS diambil dari data sekunder Data-data yang diperlukan dalam rangka penyusunan analisis daya dukung DAS terdiri dari :

1. Data lahan diperoleh dari data yang telah dianalisis di BP-DASHL Indragiri Rokan, Dinas Lingkungan Hidup dan Kehutanan.

2. Data kependudukan dari BPS Provinsi Riau

3. Data nilai investasi bangunan, diperoleh dari data sekunder yang dimiliki oleh Kementerian PU .

4. Data pemanfaatan ruang wilayah diperoleh melalui data sekunder dari instansi terkait seperti Bappeda, Dinas Lingkungan Hidup dan Kehutanan.

\section{Prosedur Penelitian}

Prosedur penelitian untuk menganalisis nilai investasi bangunan dan pemanfaatan ruang wilayah untuk penilaian daya dukung DAS Rokan adalah sebagai berikut :

1. Melakukan pengumpulan data untuk keperluan analisis seperti data kependudukan, data lahan, data investasi lahan dan data pemanfaatan ruang wilayah

2. Melakukan analisis sub kriteria klasifikasi kota

3. Melakukan analisis sub kriteria klasifikasi nilai bangunan air

4. Melakukan analisis sub kriteria klasifikasi kawasan Lindung (KL)

5. Melakukan analisis sub kriteria klasifikasi kawasan Budidaya (KL) 
6. Melakukan pembobotan, penetapan kelas, skor dan penetapan nilai hasil perkalian antara Bobot dengan Skor

7. Menetapkan kontribusi nilai investasi bangunan dan Pemanfaatan Ruang Wilayah terhadap daya dukung DAS Rokan

\section{HASIL DAN PEMBAHASAN}

DAS Rokan mencakup wilayah Provinsi Riau yang melewati Kota Pasir Pangaraian Kabupaten Rokan Hulu, Kota Bagansiapiapi Kabupaten Rokan Hilir serta Duri Kota Dumai sedangkan Provinsi Sumatera Barat melewati Lubuk Sikaping Kabupaten Pasaman. Selanjutnya bersumber dari Badan Pusat Statistik (BPS) Provinsi Riau dan Provinsi Sumatera Barat maka komposisi jumlah komposisi penduduk disajikan seperti pada Tabel 5 sebagai berikut

Tabel 5. Jumlah Penduduk dan Penetapan Klasifikasi Kota di DAS Rokan

\begin{tabular}{|l|c|l|}
\hline Kota /Provinsi & $\begin{array}{c}\text { Jumlah } \\
\text { Penduduk } \\
\text { (jiwa) }\end{array}$ & $\begin{array}{c}\text { Kasifikasi } \\
\text { Kota }\end{array}$ \\
\hline $\begin{array}{l}\text { Pasir } \\
\text { Pangaraian/ } \\
\text { Riau }\end{array}$ & 60.144 & Kota Kecil \\
\hline $\begin{array}{l}\text { Bagansiapiapi/ } \\
\text { Riau }\end{array}$ & 73.360 & Kota Kecil \\
\hline Kota Duri / Riau & 239.961 & $\begin{array}{l}\text { Kota } \\
\text { Sedang }\end{array}$ \\
\hline $\begin{array}{l}\text { Lubuk Sikaping/ } \\
\text { Sumatera Barat }\end{array}$ & 44.059 & Kota Kecil \\
\hline
\end{tabular}

Bersumber dari Permenhut No 61/Menhut II/2014 Kementerian Lingkungan Hidup dan Kehutanan Republik Indonesia menyatakan apabila di DAS terdapat lebih dari satu status/kategori kota maka digunakan status/kategori kota yang mempunyai kelas tertinggi. Dengan merujuk Tabel 1 tersebut di atas, maka Kota Duri dengan jumlah penduduk 239.961 jiwa dengan klasifikasi kota sedang mewakili dari keempat kota yang dilewati oleh DAS Rokan dengan skor sama dengan 1.00 untuk bobot 5 maka akan diperoleh nilai hasil perkalian antara bobot dan skor sebesar 5
Asset atau nilai investasi bangunan air dalam satu DAS mencerminkan besar kecilnya sumber daya buatan manusia yang telah dibangun di DAS yang perlu dilindungi dari kerusakan yang disebabkan oleh degradasi DAS. Semakin besar nilai investasi bangunan dimaksud semakin besar keperluan untuk melindunginya. Unit bangunan Air dan Nilai Investasi bangunan air di DAS Rokan disajikan pada Gambar 2 dan Gambar 3 seperti di bawah ini.

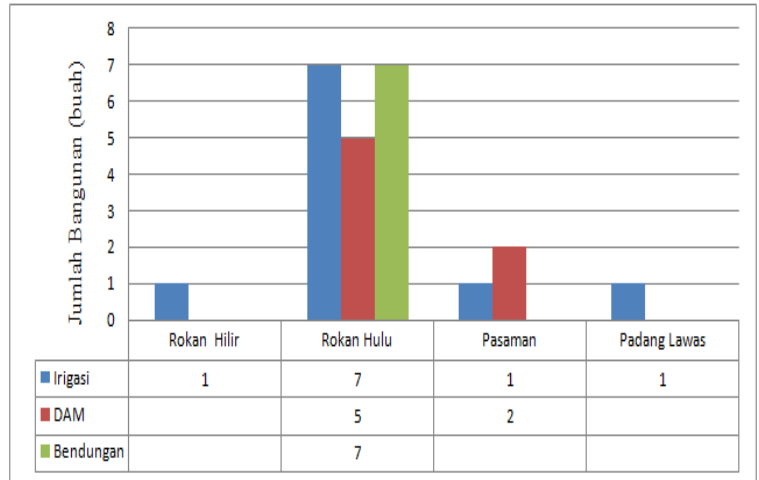

Gambar 2. Unit Bangunan Air di DAS Rokan

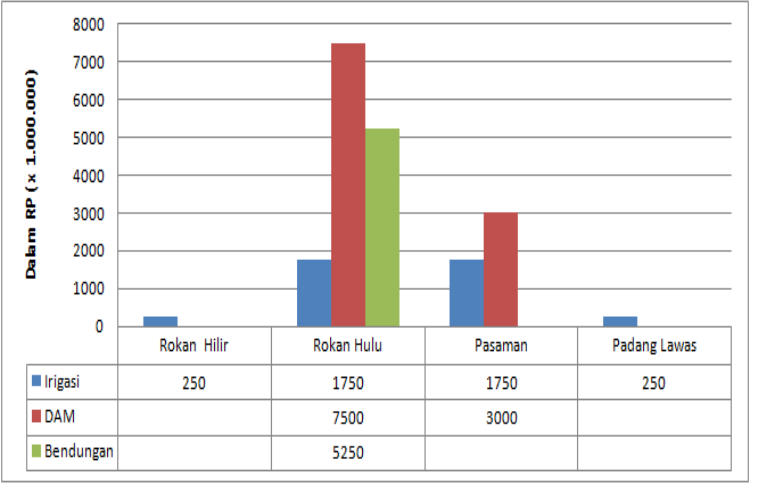

Gambar 3. Nilai Investasi Bangunan Air (dalam juta) di DAS Rokan

Merujuk dari Gambar 2 di atas, bahwa nilai total investasi nilai bangunan air di DAS Rokan adalah penjumlahan nilai investasi Bangunan Irigasi ditambah dengan nilai investasi Bangunan DAM ditambah dengan nilai investasi Bangunan Bendungan sehingga akan diperoleh nilai total IBA di DAS Rokan adalah sebesar Rp 19.750 juta atau Rp 19,75 milyar sehingga dengan merujuk Tabel 2 di atas maka nilai sub kriteria investasi Bangunan Air (IBA) Total DAS Rokan diklasifikasikan kelas rendah dengan skor 0.75 . 
Adapun rekapitulasi hasil analisis dan kriteria Investasi Bangunan selanjutnya disajikan seperti pada Tabel 6 di bawah ini

Tabel 6. Rekapitulasi Nilai Kriteria Investasi Bangunan

\begin{tabular}{|l|l|l|l|l|}
\hline \multicolumn{1}{|c|}{$\begin{array}{c}\text { Sub } \\
\text { Kriteria }\end{array}$} & $\begin{array}{c}\text { Bobo } \\
\mathrm{t}\end{array}$ & Kelas & Skor & $\begin{array}{l}\text { Bobot } \\
\text { x Skor }\end{array}$ \\
\hline $\begin{array}{l}\text { Klasifikas } \\
\text { i Kota }\end{array}$ & 5 & $\begin{array}{l}\text { Sedan } \\
\mathrm{g}\end{array}$ & 1.00 & 5.00 \\
$\begin{array}{l}\text { Nilai } \\
\text { Investasi } \\
\text { Bangunan } \\
\text { Air }\end{array}$ & 5 & $\begin{array}{l}\text { Renda } \\
\text { h }\end{array}$ & 0.75 & 3.75 \\
Total & & & & 8.75 \\
\hline
\end{tabular}

Sumber : Hasil analisis

\section{Monitoring dan Evaluasi Sub Kriteria Kawasan Lindung}

Kawasan lindung adalah wilayah yang ditetapkan dengan fungsi utama melindungi kelestarian lingkungan hidup yang mencakup sumber daya alam dan sumber daya buatan (UU RI No.37 tentang Konservasi Tanah Air, 2014). Karekteristik lahan dengan kondisi lereng yang curam dan tanah peka erosi merupakan salah satu kawasan yang perlu dilindungi. Kawasan lindung dengan karakteristik ekologis yang unik perlu tetap dipertahankan jangan sampai ekosistemnya terganggu, misalnya penutupan lahan yang berada di atasnya

Bersumber dari data analisis spasial yang telah dilakukan oleh BP-DASHL Indragiri Rokan terkait sub kriteria Kawasan Lindung didapat hasil informasi sebagai berikut

1. Luas DAS Rokan : 2.009.768.05 ha

2. Luas Liputan Vegetasi Hutan : 208.921, 56 ha

3. Luas kawasan lindung dalam DAS 1.306.964,11ha

Dengan menggunakan persamaan $1 \mathrm{di}$ atas, maka dapat diperoleh nilai kawasan lindung (KL) sebagai berikut :

$$
\begin{aligned}
K L & =\frac{208.921,56}{1.306 .964,11} \times 100 \% \\
K L & =16 \%
\end{aligned}
$$

Merujuk Tabel 3 di atas hasil analisis Kawasan Lindung di DAS Rokan dengan nilai $16 \%$ ada pada rentang $15<\mathrm{KL}<30$ maka mengindikasikan bahwa DAS Rokan memiliki kelas kondisi buruk dengan skor 1.25. Bila merujuk Undang-Undang (UU) Republik Indonesia No 41 tahun 1999 tentang Kehutanan, menyebutkan bahwa penyelenggaraan kehutanan yang bertujuan untuk sebesar-besar kemakmuran rakyat adalah dengan meningkatkan daya dukung DAS dan mempertahankan kecukupan hutan minimal 30\% dari luas DAS dengan sebaran proporsional. Ini artinya liputan vegetasi hutan di DAS Rokan tidak sesuai yang diamanat UU Republik Indonesia No.41 Tahun 1999 tentang Kehutanan, hal ini tutupan vegetasi hutan perlu ditingkatkan menjadi minimal $30 \%$.

\section{Monitoring dan Evaluasi Sub Kriteria Kawasan Budidaya}

Kawasan Budidaya adalah wilayah yang ditetapkan dengan fungsi utama untuk dibudidayakan atas dasar kondisi dan potensi sumber daya alam, sumber daya manusia dan sumber daya buatan (UU No.37 tentang Konservasi Tanah dan Air, 2014). Kawasan budidaya memiliki karakteristik ekologis dengan kelerengan yang relatif datar dan kondisi tanah yang tidak peka terhadap erosi. Dari segi kelas kemampuan lahan, kawasan budidaya semestinya berada pada kelas I, II, III dan IV. Kelas I dan II cocok dimanfaatkan untuk kawasan budidaya tanaman semusim, sedangkan kelas III dan IV sesuai dimanfaatkan untuk kawasan budidaya tanaman tahunan

Masih bersumber dari data analisis spasial yang telah dilakukan oleh BP-DASHL Indragiri Rokan terkait sub kriteria Kawasan Budidaya didapat hasil sebagai berikut

1. Luas DAS Rokan : 2.009.768.05 ha

2. Luas Lahan Dengan Lereng kurang 25\%: 1.481.323,89 ha

3. Luas kawasan Budidaya dalam DAS Rokan 1.706.920,62 ha

Dengan menggunakan persamaan 2 di atas, maka dapat diperoleh nilai kawasan Budidaya (KB) sebagai berikut :

$$
\begin{aligned}
K B & =\frac{1.481 .323,89}{1.706 .920 .62} x 100 \% \\
K B & =86.8 \%
\end{aligned}
$$

Merujuk Tabel 5 di atas hasil analisis terkait Kawasan Lindung di DAS Rokan bernilai $86.8 \%$ dengan rentang KB>70 maka mengindikasikan bahwa DAS 
Rokan memiliki kelas kondisi sangat rendah dengan skor 0.5. Hasil analisis membuktikan bahwa DAS Rokan sangat sesuai dengan kondisi topografi yang relatip datar untuk kawasan budidaya

DAS Rokan termasuk dalam kategori sangat rendah, sebesar $86,7 \%$ kelerengan $<25 \%$ berada dalam kawasan budidaya, hal ini sesuai dengan karakteristik kawasan budidaya dimana kondisi topografi yang relative datar yang sesuai untuk kawasan budidaya

Tabel 7. Rekapitulasi Nilai Pemanfaatan Ruang Wilayah

\begin{tabular}{|l|l|l|l|l|}
\hline \multicolumn{1}{|c|}{$\begin{array}{c}\text { Sub } \\
\text { Kriteria }\end{array}$} & $\begin{array}{c}\text { Bobo } \\
\mathrm{t}\end{array}$ & Kelas & Skor & $\begin{array}{l}\text { Bobot } \\
\text { x Skor }\end{array}$ \\
\hline $\begin{array}{l}\text { Kawasan } \\
\text { Lindung } \\
\text { (LK) }\end{array}$ & 5 & Buruk & 1.25 & 6.25 \\
$\begin{array}{l}\text { Kawasan } \\
\text { Budidaya } \\
\text { (KB) }\end{array}$ & 5 & $\begin{array}{l}\text { Sangat } \\
\text { Renda } \\
\text { h }\end{array}$ & 0.5 & 2.50 \\
Total & & & & 8.75 \\
\hline
\end{tabular}

Sumber : Hasil analisis

\section{KESIMPULAN}

Berdasarkan hasil analisis dan pembahasan di atas maka dapat ditarik kesimpulan sebagai berikut

1. Nilai kriteria Investasi Bangunan dan kriteria Pemanfaatan Ruang Wilayah juga masingmasing sebesar 8.75 sehingga akan memberikan sumbangan nilai terhadap kebutuhan analisis daya dukung DAS Rokan sebesar 17 poin.

2. Kriteria Pemanfaatan Ruang Wilayah khususnya sub kriteria Kawasan Lindung (KL) yang perlu mendapat perhatian serius dalam pengelolaan DAS Rokan dengan melakukan rencana aksi perlindungan terhadap Lahan Kawasan Lindung (KL) tutupan vegetasi hutan di DAS Rokan untuk ditingkatkan menjadi minimal 30\% agar kecukupan hutan selaras dengan amanah UU RI No.41 Tahun 1999.

\section{UCAPAN TERIMA KASIH}

Penulis mengucapkan terima kasih kepada Badan Pusat Statistik (BPS) Provinsi Riau, Balai Pengelolaan Daerah Aliran Sungai dan Hutan Lindung (BPDASHL) Indragiri Rokan serta Dinas PU-PR Provinsi Riau yang telah berkenan memberi bantuan data sekunder untuk kebutuhan analisis terhadap penilaian Daya Dukung DAS Rokan

\section{DAFTAR PUSTAKA}

Asdak, C., 2010. Hidrologi dan Pengelolaan Daerah Aliran Sungai. Gadjah Mada University Press, Yogyakarta

2015. Laporan Akhir Rencana Umum Pengelolaan DAS Kampar Pusat Pengendalian Pembangunan Ekoregion Sumatera (P3ES) Kementerian Lingkungan Hidup dan Kehutanan (LHK) Republik Indonesia.

2014. Peraturan Menteri Kehutanan No.61/Menhut II/ 2014 Tentang Monitoring dan Evaluasi Daerah Aliran Sungai (DAS), Kementerian Lingkungan Hidup dan Kehutanan (LHK) Republik Indonesia.

1999. Undang-Undang Republik Indonesia Nomor 41 Tahun 1999 Tentang Kehutanan, Pemerintah Republik Indonesia.

2014. Undang-Undang Republik Indonesia Nomor 37 Tahun 2014 Tentang Konservasi Tanah dan Air , Pemerintah Republik Indonesia.

......,2008. Peraturan Pemerintah (PP) Republik Indonesia Nomor 26 Tahun 2008 Tentang Rencana Tata Ruang Wilayah Nasional (RTRWN), Pemerintah Republik Indonesia 